$$
\begin{gathered}
\text { UNIVERSITY OF CALIFORNIA } \\
\text { COLLEGE OF AGRICULTURE } \\
\text { AGRICULTURAL EXPERIMENT STATION } \\
\text { BERKELEY, CALIFORNIA }
\end{gathered}
$$

\title{
FORCING GLADIOLUS OUTDOORS BY HEATING THE SOIL WITH ELECTRICITY
}

JAMES R. TAVERNETTI AND S. L. EMSWELLER

\section{BULLETIN 584}

OCTOBER, 1934 



\section{FORCING GLADIOLUS OUTDOORS \\ BY HEATING THE SOIL WITH ELECTRICITY ${ }^{1,2}$}

JAMES R. TAVERNETTI ${ }^{3}$ AND S. L. EMSWELLER ${ }^{4}$

THE GROWING OF GLADIOLUS OUTDOORS for cut flowers is an important part of the floral industry in the United States. According to the Census of 1930, this crop then comprised slightly over 26 per cent of the land area used and over 29 per cent of the value of all cut flowers grown in the open. This popularity results from the wide adaptability of the gladiolus to different types of climatic and soil conditions and from its use both as a cut flower and as a decorative plant. The wide range of color and type, the ease of growing, and the long season of bloom are also contributing factors.

Although the early cut flowers bring a higher price, little or no attempt has been made to produce them outdoors. The common practice is to plant the corms as soon as possible for the earliest crop and to make successive plantings every few weeks. The time required to produce the flowers varies with the climate. It is often unduly prolonged by low soil temperatures that cause early planted corms to lie dormant for a long period.

Because of its convenient adaptability and relatively low initial cost, heating the soil by electricity has recently stimulated interest in the forcing of gladiolus outdoors. In order to determine the effect and costs of this method of forcing outdoors, a series of experiments was conducted at Davis during the winter and spring seasons of 1931, 1932, and 1933. The first year, plants were grown in an uncovered frame; the second, in the open field; and the third, in a covered frame.

In all the experiments the corms used were between $1 \frac{1 / 2}{2}$ and 2 inches in diameter. They were dug about October and were held in storage

1 Received for publication July 6, 1934.

2 This publication is the twelfth of a series reporting results of investigations conducted by the California Agricultural Experiment Station in coöperation with the California Committee on the Relation of Electricity to Agriculture.

3 Associate in Agricultural Engineering.

4 Assistant Professor of Truck Crops and Assistant Olericulturist in the Experiment Station. 
until planted in a basement where the temperature varied between $54^{\circ}$ and $59^{\circ}$ Fahrenheit. Each year all corms were dipped in Semesan as soon as they had dried out after harvest, and again a few days before planting. Only sound, healthy ones were used.

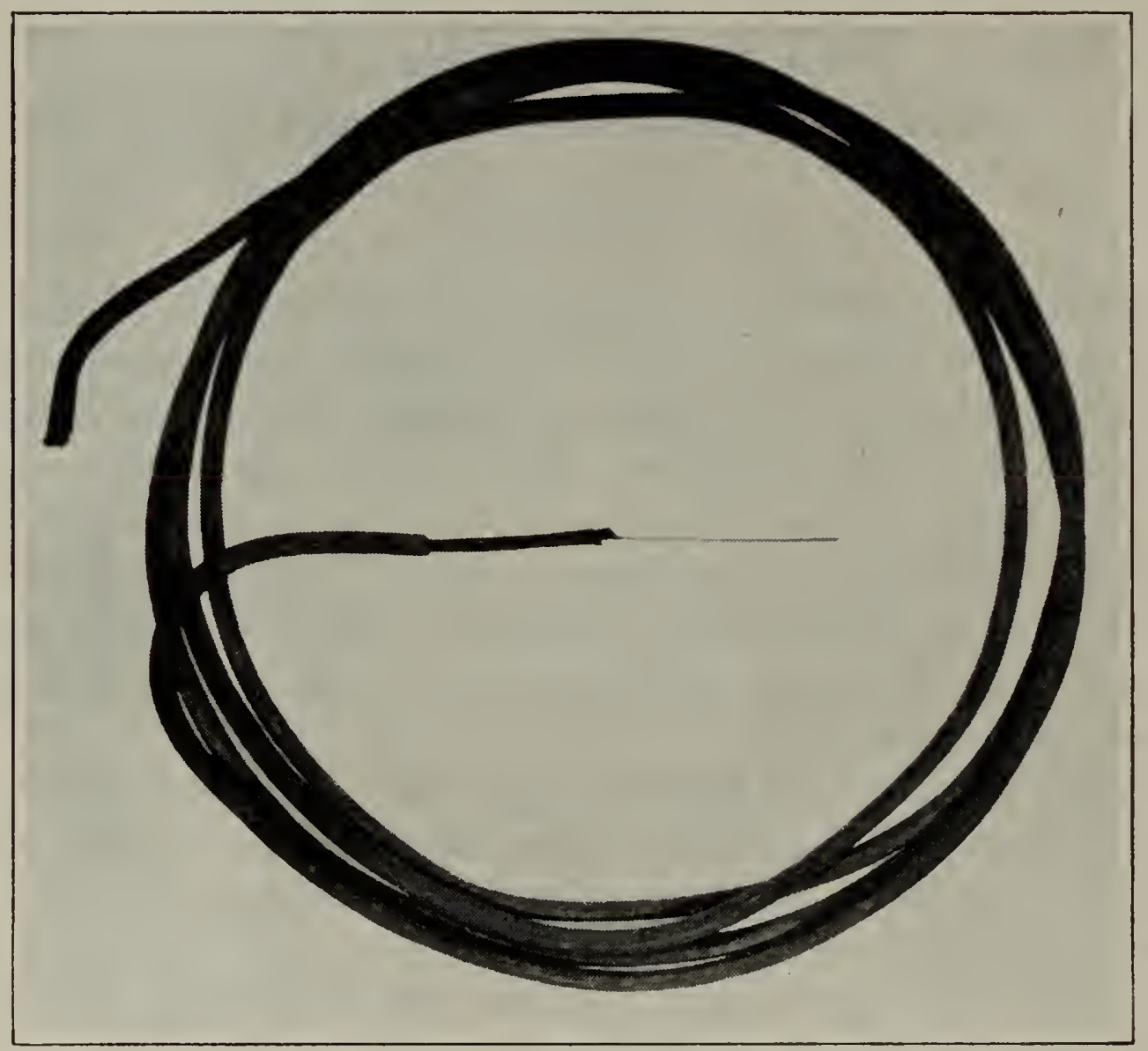

Fig. 1.-A piece of the heating cable used for warming the soil. It consists of an insulated resistance wire enclosed in a lead sheath. A 60 -foot length connected to a 110 -volt circuit will heat about 4 square yards of soil. This cable costs about five cents per foot.

The soil was warmed by a special heating cable (fig. 1), consisting of a resistance wire insulated with felted asbestos and enclosed in a lead sheath about $1 / 4$ inch in diameter. This cable had a resistance of $1 / 2 \mathrm{ohm}$ per foot and was connected to a 110-volt circuit.

\section{FORCING IN UNCOVERED FRAMES}

In 1931 the corms were grown in an uncovered frame $6 \times 15$ feet, half of which was heated and half unheated (fig. 2). A space of 1 foot was left between the two plots. The heat was furnished by 45 feet of soilheating cable, which was looped back and forth, as shown in figure 2, and buried 5 inches deep in trenches 12 inches apart. The total connected load was about 500 watts for the bed or about 12 watts per square foot. 
Fifty-four corms of the Prince of Wales and 36 of the Shaylor varieties were planted in each bed on December 15, 1930. There was 1 foot between the rows, which were midway between the legs of the cable loops; and the corms were spaced 4 inches apart at a depth of 3 inches.

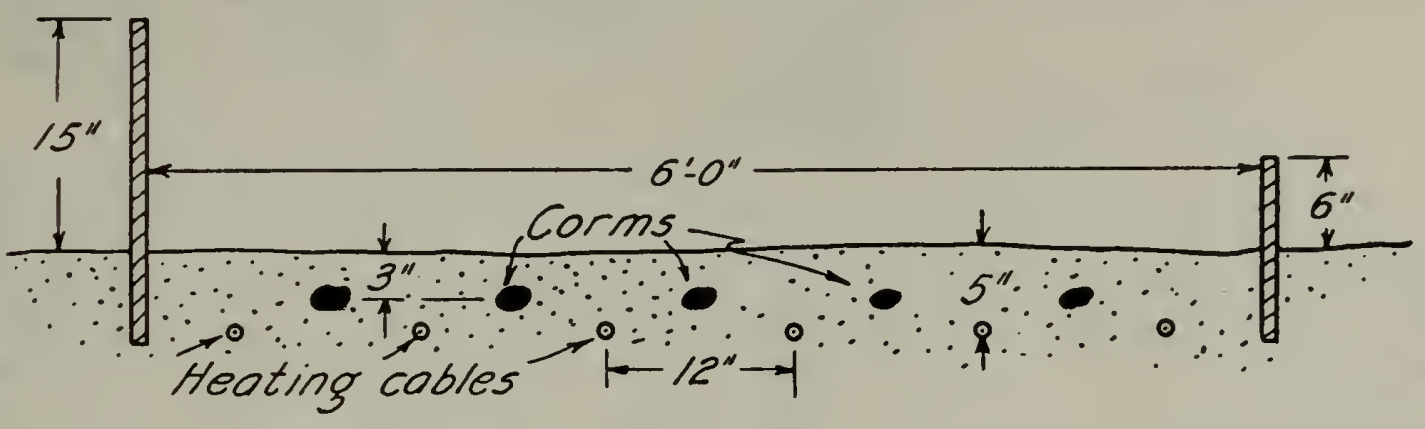

$A$

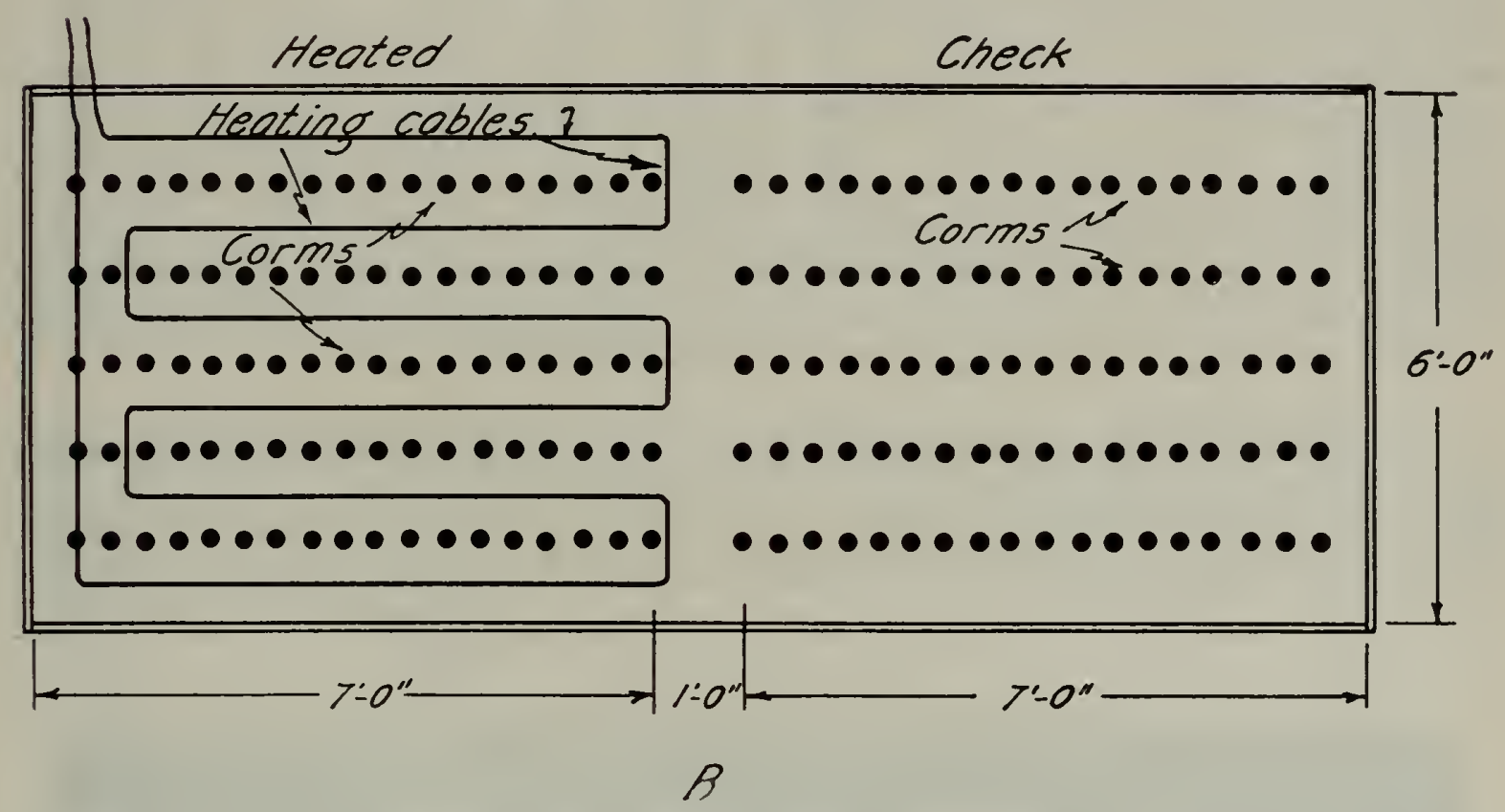

Fig. 2.-A, Cross section, and $B$, plan of heated and check beds in the uncovered frame.

The heat was first applied on January 14, 1931, and was left on until April 20 (96 days). During this time it was automatically controlled through a thermostat by the temperature in the top 10 inches of soil at a point midway between two legs of a cable loop. The ranges of temperature for both soil and air were recorded during the period of heating. They are given in table 1 along with the electrical energy consumed. During the heating period, the average range of soil temperature $\left(73^{\circ}\right.$ to $\left.80^{\circ} \mathrm{F}\right)$ in the heated bed was about $16^{\circ}$ higher than in the check bed $\left(58^{\circ}\right.$ to $\left.63^{\circ} \mathrm{F}\right)$. This difference varied from about $20^{\circ}$ during the first few weeks to about $5^{\circ}$ during the last weeks. The energy consumption averaged 1.19 kilowatt-hours per square yard per day or a total of 114 kilowatt-hours per square yard for the entire heating period. 


\section{TABLE 1}

Energy Consumption and Range of Soll and Air Temperatures for EXPERIMENTS IN UNCOVERED FraMe, 1931

\begin{tabular}{|c|c|c|c|c|c|c|c|}
\hline \multirow{2}{*}{ Period } & \multirow{2}{*}{$\begin{array}{c}\text { Energy con- } \\
\text { sumption, } \\
\text { kw.-hrs. per } \\
\text { square yard } \\
\text { per day }\end{array}$} & \multicolumn{2}{|c|}{$\begin{array}{l}\text { Soil } \\
\text { temperatures* } \\
\text { in heated bed, } \\
\text { deg. Fahr. }\end{array}$} & \multicolumn{2}{|c|}{$\begin{array}{l}\text { Soil } \\
\text { temperatures* } \\
\text { in unheated bed } \\
\text { deg. Fahr. }\end{array}$} & \multicolumn{2}{|c|}{$\begin{array}{l}\text { Air } \\
\text { temperatures } \\
\text { around beds. } \\
\text { deg. Fahr. }\end{array}$} \\
\hline & & $\begin{array}{l}\text { Av. } \\
\text { min. }\end{array}$ & $\begin{array}{l}\text { Av. } \\
\text { max. }\end{array}$ & $\begin{array}{l}\text { Av. } \\
\text { min. }\end{array}$ & $\begin{array}{l}\text { Av. } \\
\text { max. }\end{array}$ & $\begin{array}{l}\text { Av. } \\
\text { min. }\end{array}$ & $\begin{array}{l}\text { Av. } \\
\text { max. }\end{array}$ \\
\hline January 14 to 25 & 1.78 & & & 47 & 50 & 36 & 57 \\
\hline January 26 to February 1 & 1.50 & 70 & 76 & 51 & 55 & 40 & 59 \\
\hline February 2 to 8 & 1.47 & 73 & 75 & 54 & 58 & 44 & 64 \\
\hline February 9 to 15 & 0.89 & 74 & 76 & 56 & 60 & 44 & 63 \\
\hline February 16 to $22 \ldots$ & 0.28 & 66 & 73 & 54 & 60 & 40 & 62 \\
\hline February 23 to March $1 .$. & 1.65 & 72 & 79 & 55 & 60 & 38 & 65 \\
\hline March 2 to 8 & 1.16 & 74 & 83 & 58 & 65 & 38 & 72 \\
\hline March 9 to 15 & 1.38 & 73 & 82 & 58 & 63 & 42 & 67 \\
\hline March 16 to $22 \ldots$ & 0.98 & 73 & 82 & 62 & 66 & 45 & 72 \\
\hline March 23 to $29 \ldots \ldots$ & 1.26 & 75 & 83 & 61 & 66 & 39 & 67 \\
\hline March 30 to April 6 & 1.04 & 74 & 86 & 64 & 69 & 40 & 77 \\
\hline April 7 to $13 \ldots \ldots$ & 1.01 & 75 & 86 & 67 & 72 & 44 & 79 \\
\hline April 14 to $20 \ldots$ & 0.64 & 73 & 83 & 70 & 80 & 45 & 84 \\
\hline Average. & 1.19 & 73 & 80 & 58 & 63 & 41 & 68 \\
\hline
\end{tabular}

* The soil temperatures are the average in the top 11 inches of soil.

The growth in the heated bed was always considerably more advanced than that in the check bed (fig. 3). At first the foliage was a light green, but as the season advanced it became normal; and the quality of flowers produced was in no way inferior. In the heated bed, both varieties be-

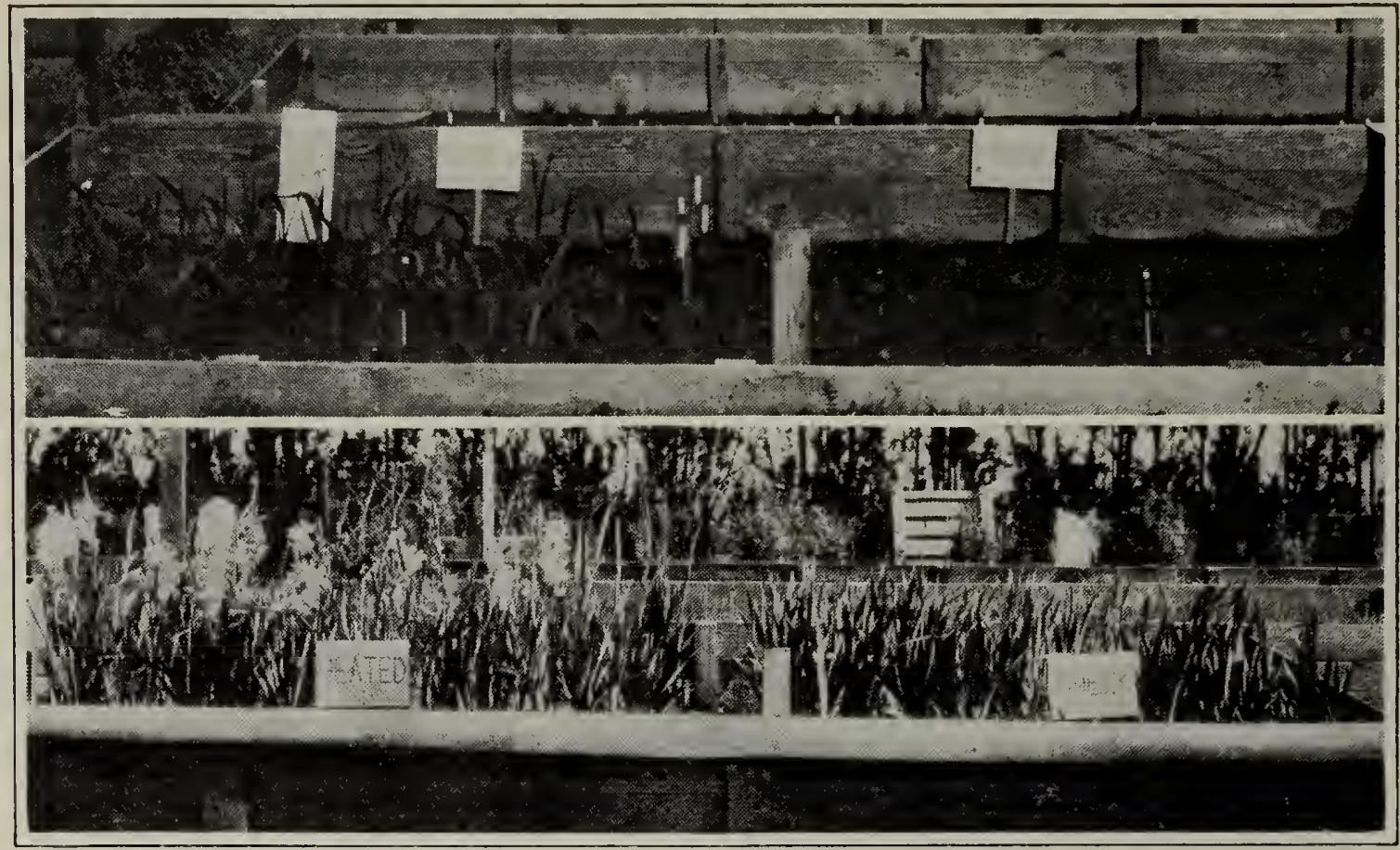

Fig. 3.-The upper picture was taken on February 8 ; the lower on April 28, 1931. The heated plot was consistently earlier in growth and flowering. 
gan to bloom ${ }^{5}$ about two weeks earlier than in the unheated (fig. 4) and had finished before 25 per cent of the latter had bloomed. All the Prince of Wales variety were harvested 25 days before the last spike was cut

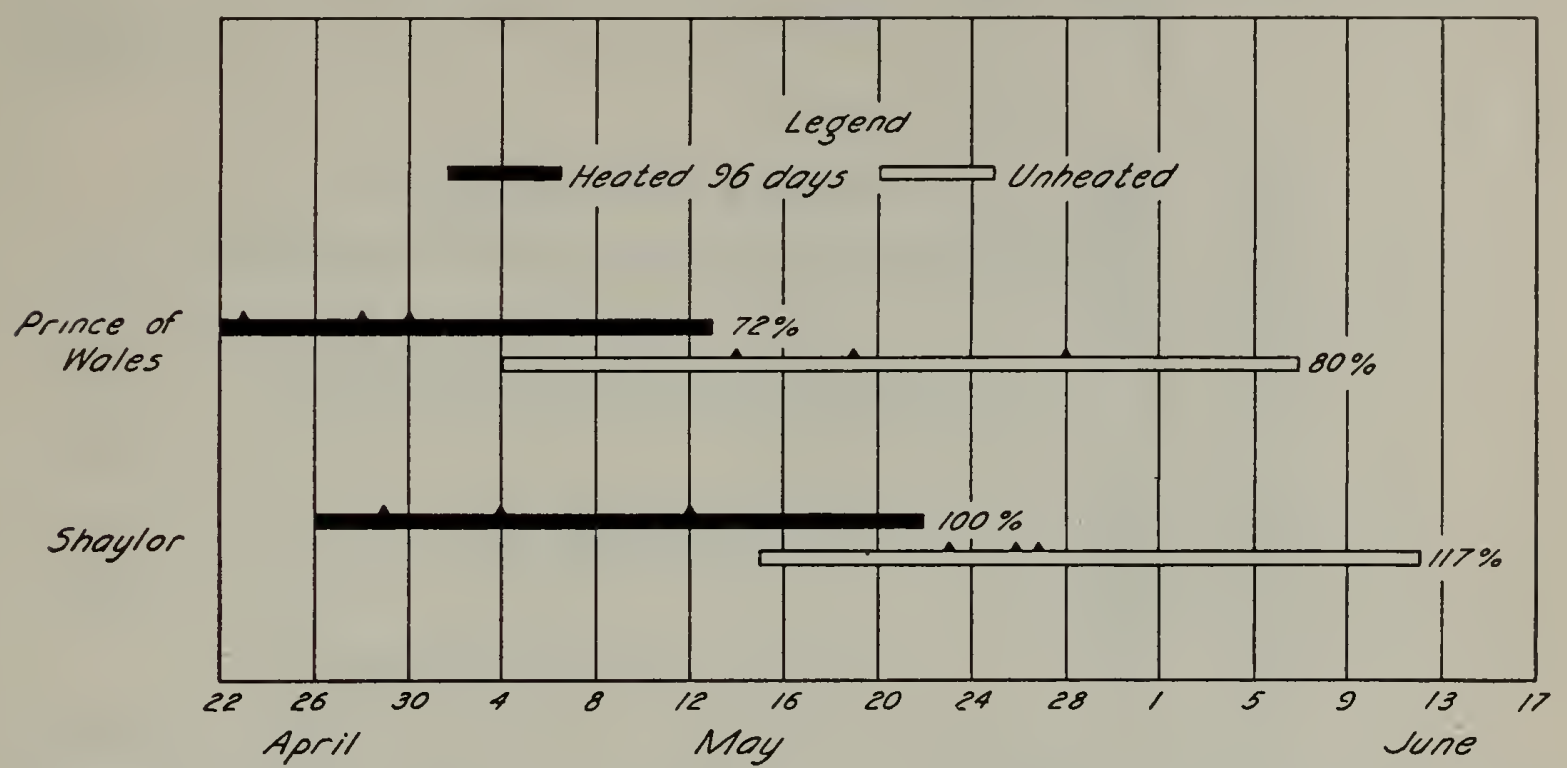

Fig. 4.-Blooming period of gladiolus in the uncovered frame. Points on the bars indicate dates when 25,50 , and 75 per cent, respectively, of the spikes were harvested. The figures at the ends of the bars show percentages of spikes harvested in relation to the number of corms planted.

on the check plot, while the Shaylor variety showed a difference of 21 days in favor of the heated. The percentage of corms blooming is slightly. in favor of the check plots, but it may not be significant, since the number involved is small.

\section{FORCING IN THE OPEN FIELD}

In 1932, eight beds in the open field, each 18 inches wide and 26 feet long, were used, four being heated and four unheated (fig. 5). In each heated bed a single circuit of 52 feet of soil-heating cable was buried to

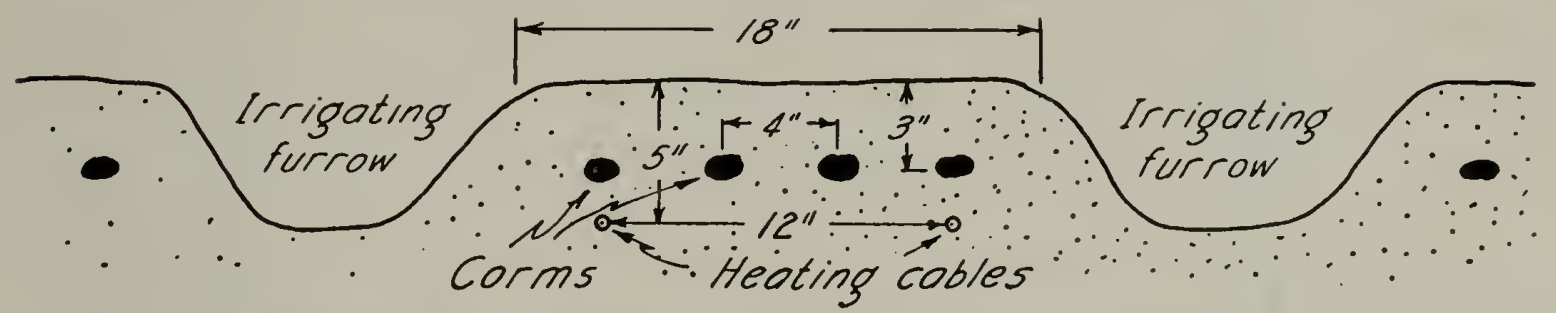

Fig. 5.-Cross section of the heated bed in the open field.

a depth of about 5 inches. It was placed in a hairpin loop running the length of the bed with the legs spaced about 12 inches apart. The connected load in each bed was about 475 watts, or about 12 watts per square foot.

5 Spikes were considered mature when the first flower opened. 


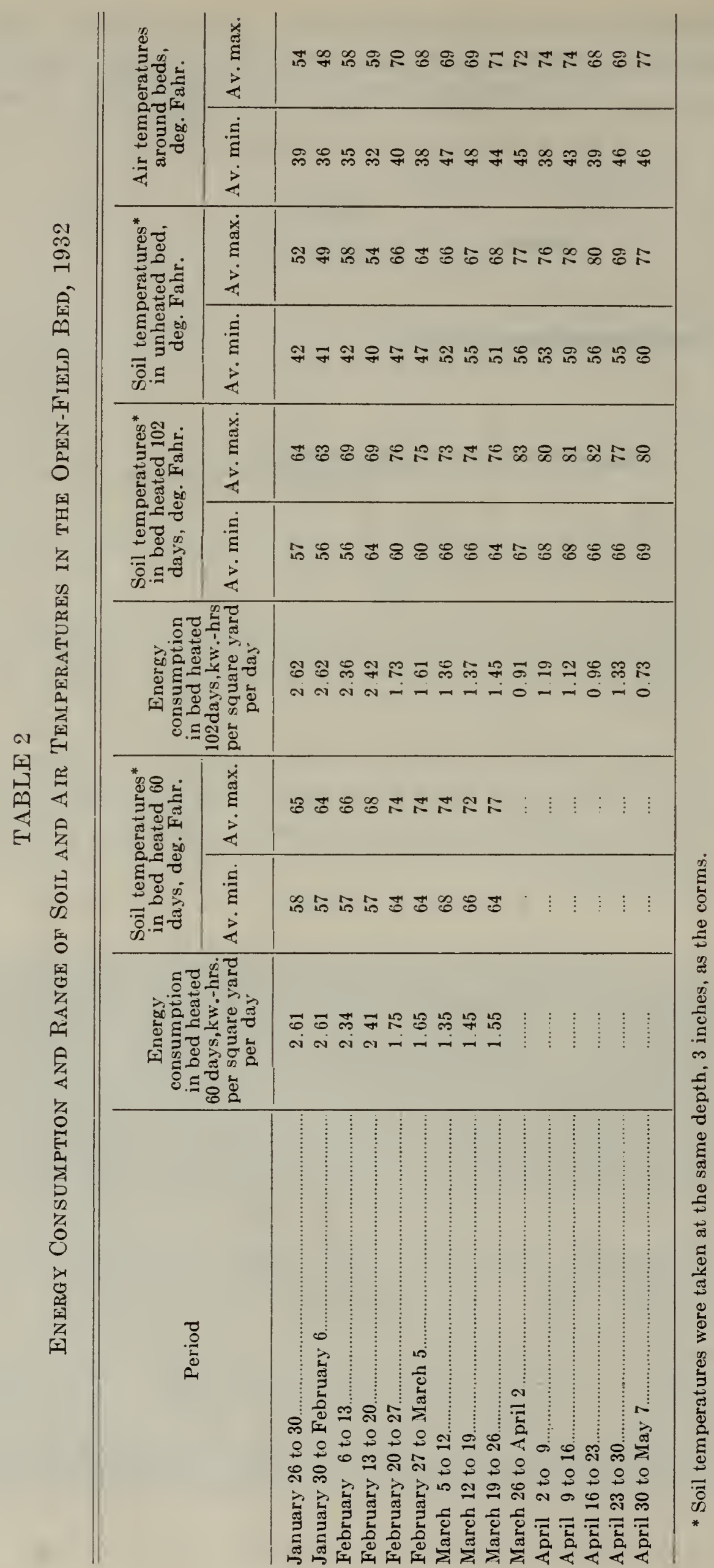


Six varieties of gladiolus-Rose of 1910, Jack London, Shaylor, Scarlano, Prince of Wales, and Bothkin-were planted on November 11, 1931. The rows were run across the beds, spaced 8 inches apart; and four corms were planted about 3 inches deep and 4 inches apart in each row.

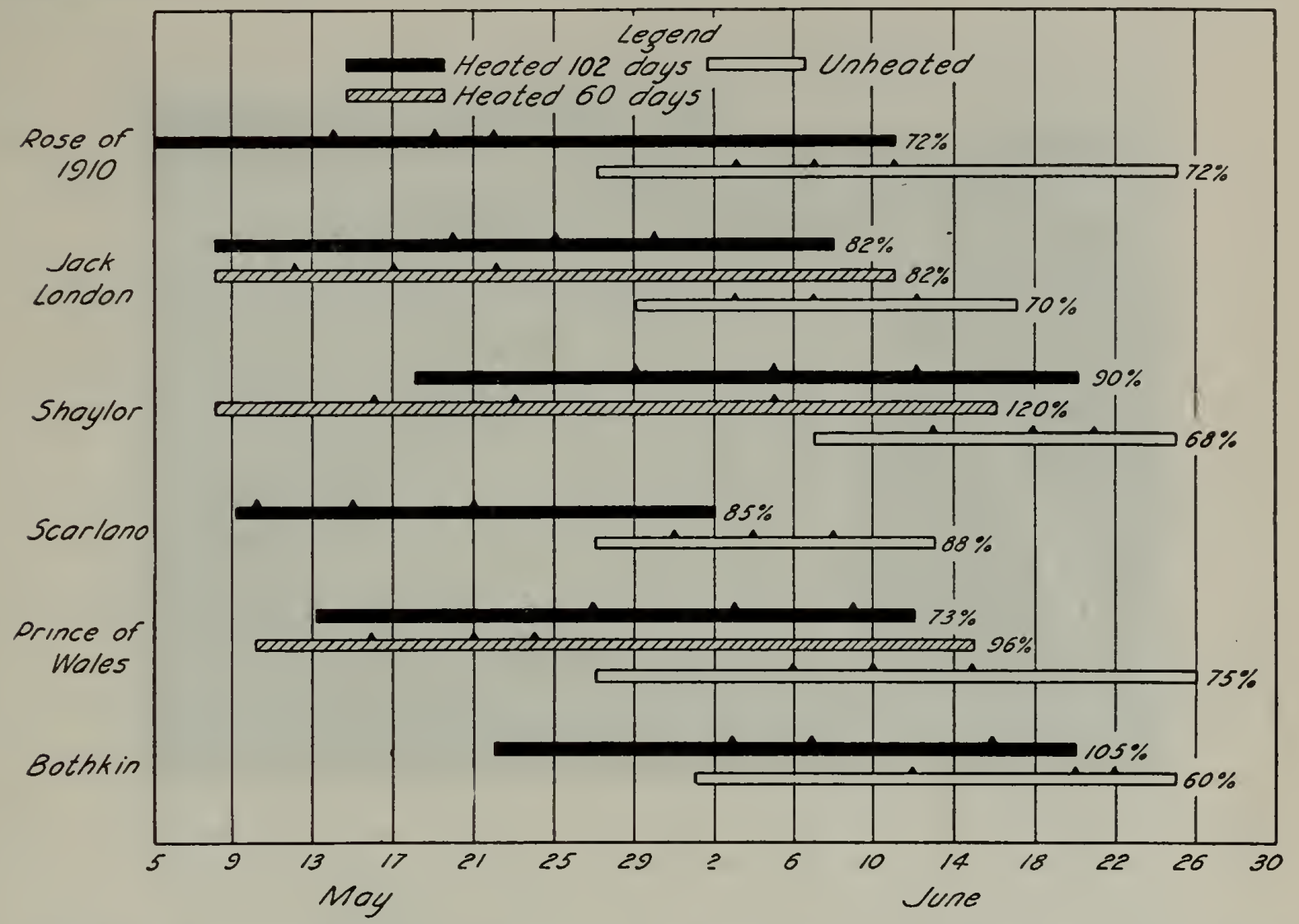

Fig. 6.-Blooming period of gladiolus in open-field beds. Points on the bars indicate dates when 25,50 , and 75 per cent, respectively, of the spikes were harvested. The figures at the ends of the bars show percentages of spikes harvested in relation to the number of corms planted.

The current was first turned on in all four heated beds on January 26, 1932. In three it was left on until May 7 (102 days), and in the fourth until March 26 (60 days). The heat was automatically regulated by a thermostat that was controlled by the soil temperature at a point midway between the legs of the cable and at the same depth as the corms. The thermostat was set to turn the electric current on at $60^{\circ}$ and off at $66^{\circ} \mathrm{F}$.

Table 2 gives the electrical energy consumed and the temperature range for the various beds during the periods of heating. It shows a very close agreement of the soil temperatures and energy consumption in the heated beds during the first 60 days. The minimum soil temperature during this period averaged $16^{\circ}$ warmer than in the unheated bed, whereas during the succeeding 38 -day period it averaged $11^{\circ}$ warmer. Although soil-temperature readings were not taken after the heat was discontinued in the 60-day bed, in all probability they were the same 
as those in the unheated bed for the same period. The energy consumed in the bed heated 102 days dropped from an average of 1.95 kilowatthours during the first 60 days to 1.04 during the last 38 days of heating.

The blooming periods are shown graphically in figure 6 . Of the six varieties planted, three-Jack London, Shaylor, and Prince of Wales-

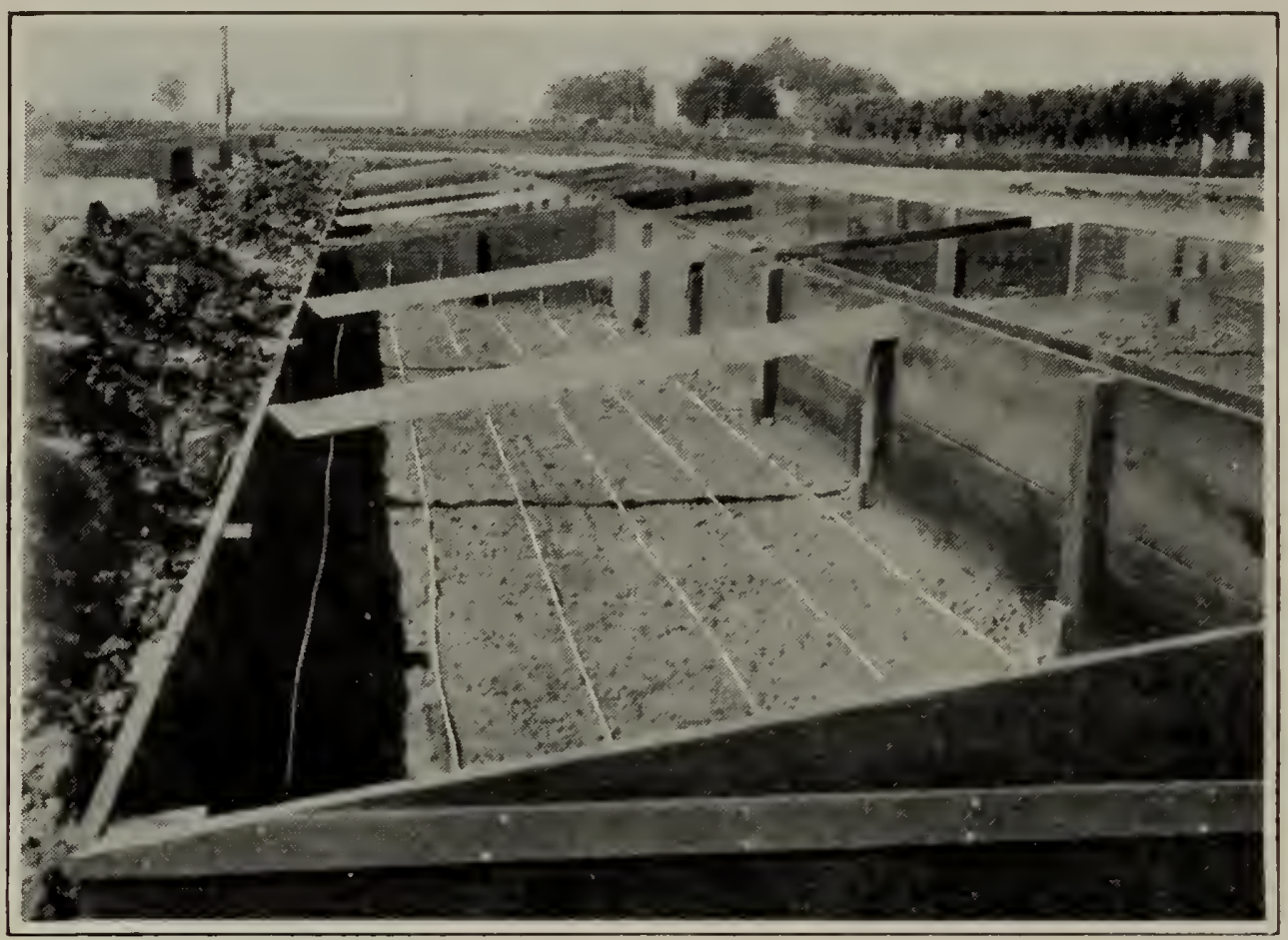

Fig. 7.-View of a heated bed in a covered frame, showing the heating cable in place ready to be covered with 3 inches of soil. After the bulbs were planted, 3 more inches of soil was placed over them.

were exposed to both the 60 and 102-day periods of heating. In each instance those receiving the shorter period of heat began blooming before or as soon as those receiving the maximum amount, 75 per cent of Prince of Wales and over 50 per cent of Jack London and Shaylor being harvested before one-fourth of the 102-day plots had bloomed. In all varieties the unheated corms began to bloom from 10 to 22 days later than the heated.

The percentage of blooms shows a rather marked difference in some varieties. This was partly caused by a prolonged period of high temperatures about the middle of June, when the young buds were so badly scorched that they never recovered sufficiently to produce a normal spike.

\section{FORCING IN COVERED FRAMES}

In 1933 the plantings were made in four $6 \times 30$-foot outdoor frames, three of which were heated and one unheated. During the first nine weeks of the heating period, all the frames were covered at night and on cloudy days by sash made of wax-impregnated muslin. In each of the 


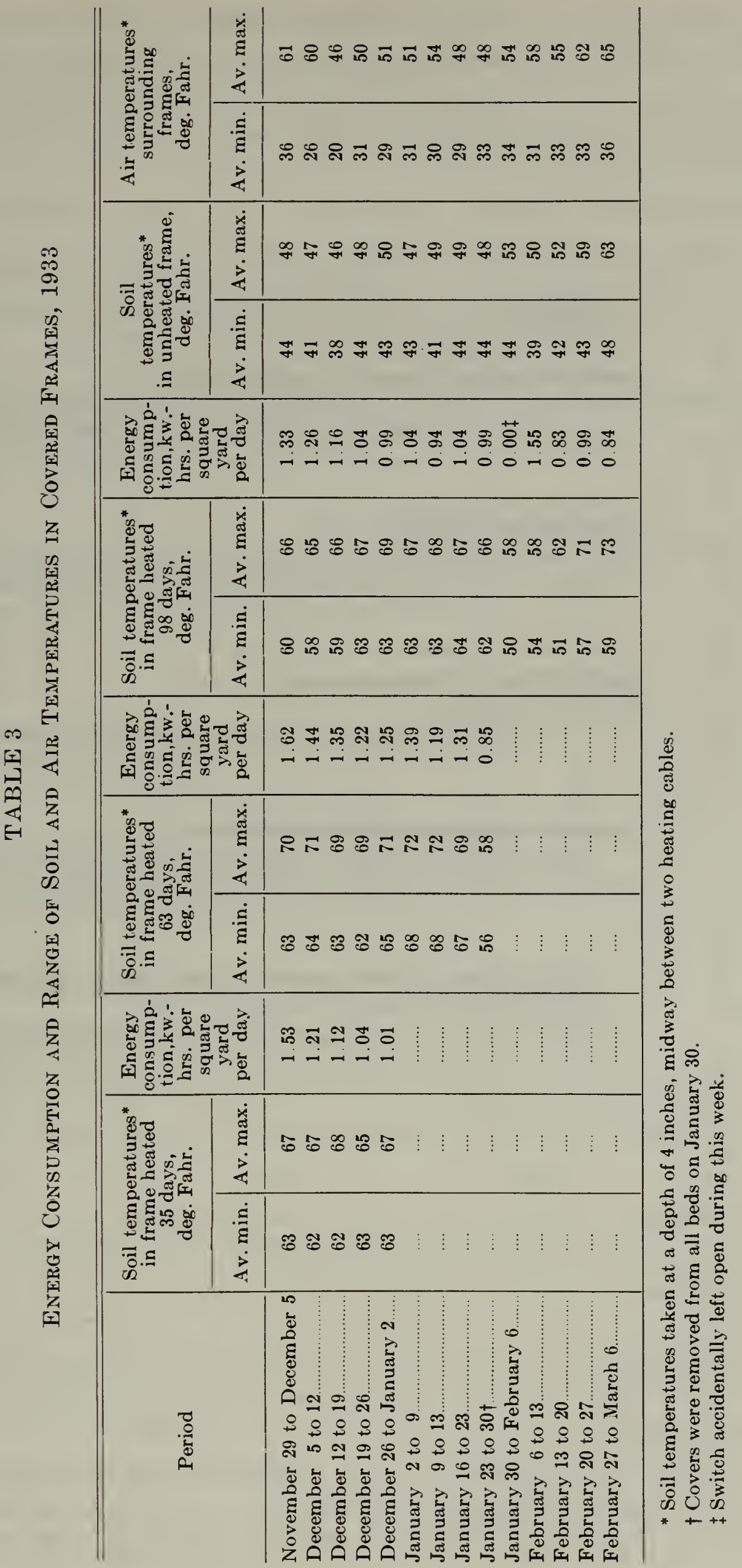


heated frames (fig. 7) were three 60 -foot lengths of soil-heating cable buried to a depth of 6 inches. Each was arranged in a hairpin loop running the length of the frame with the legs spaced 12 inches apart. There was a total connected load of about 1,200 watts per frame or $62 / 3$ watts per square foot.

The corms of five varieties of gladiolus-Los Angeles, Jack London,

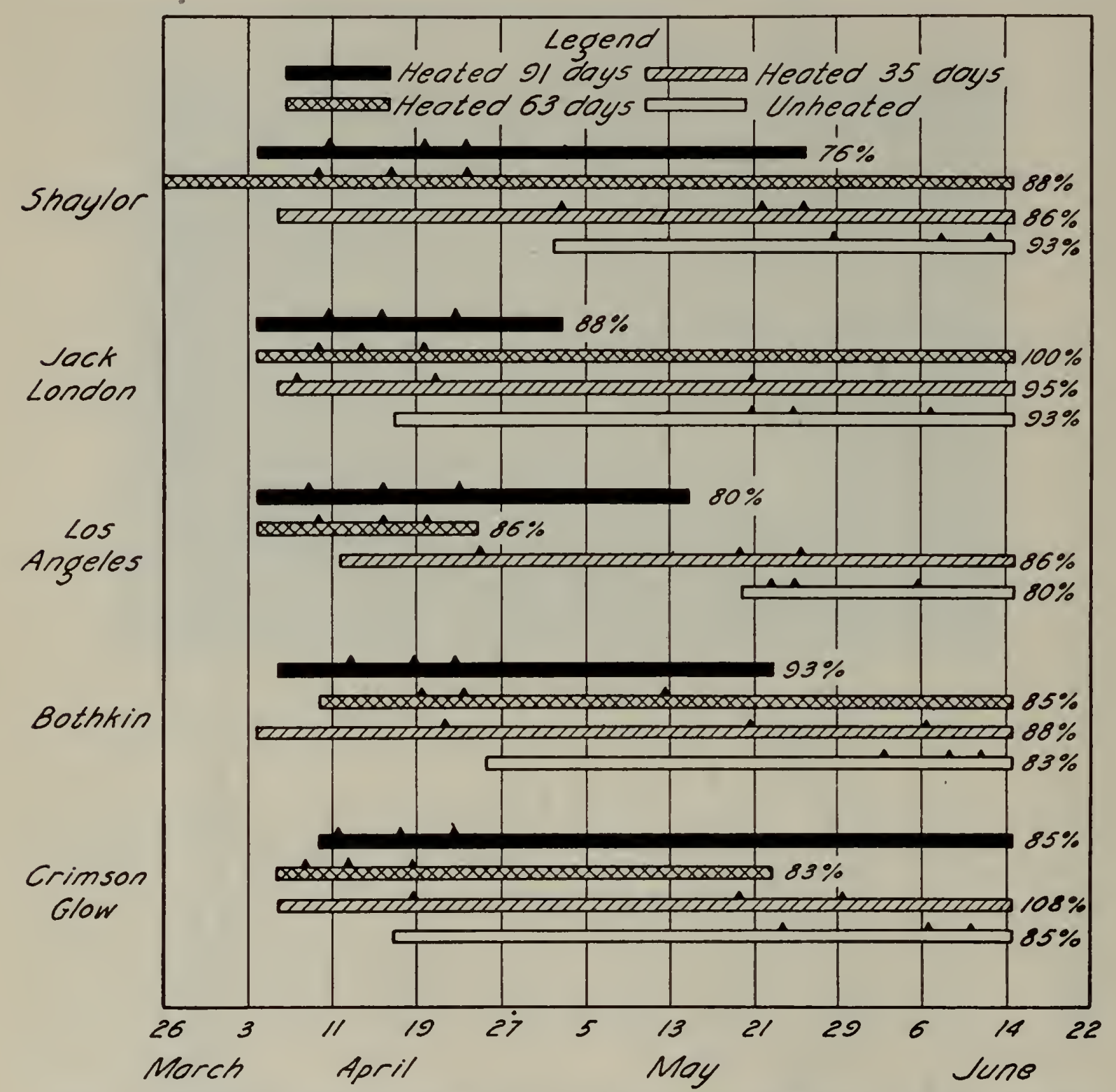

Fig. 8.-Blooming period of gladiolus in the covered frames. Points on the bars indicate dates when 25,50 , and 75 per cent, respectively, of the spikes were harvested. The figures at the ends of the bars show percentages of spikes harvested in relation to the number of corms planted.

Bothkin, Crimson Glow, and Shaylor-were planted in each bed on October 19, 1932. They were set at a depth of 3 inches and spaced 5 inches apart each way.

The heat was first applied in all the heated beds on November 29. It was left on in one until January 2 (35 days), in another until January 30 (63 days), and in the third until March 6 (98 days). In the third 
bed, however, the main switch was accidentally left open during the week of January 30 to February 6 , so that it was heated only 91 days. The temperature in each bed was automatically controlled through individual thermostats buried at the same depth and midway between two of the cables. The thermostats were set to turn on the electricity at $62^{\circ}$ and off at $68^{\circ} \mathrm{F}$.

The energy consumption and range of temperatures in the various beds during the heating periods are shown in table 3. From November 29 to January 30 the soil temperatures averaged about $20^{\circ}$ warmer in the heated than in the unheated bed. From January 30 to February 6 the temperatures cannot be compared because the heat was accidentally left off. It is interesting to note, however, that the temperature did not become so low in the heated as in the unheated bed. This was due to the retention of the heat in the soil for several days after the electricity was turned off. From February 6 to March 6, the period when the beds were uncovered, the temperature in the one bed that was still being heated was about 11 degrees warmer than in the unheated.

The results obtained in the covered frames were in complete accord with those secured in the uncovered and open-field beds. They also indicated that the beneficial effect of soil heating was in the early stages of growth and that continuous heating was not necessary. In each instance the heated plots began blooming first and at practically the same date (fig. 8). The time required, however, for 75 per cent of the plants to bloom was considerably shorter on the plots heated 91 and 63 days than on the one heated for 35 days. All varieties except Bothkin showed a more favorable response to the 63 -day period. In practically all varieties, 75 per cent of the heated corms had been cut before 25 per cent of the unheated were harvested.

The percentage of corms producing flowers shows slight variations in the different treatments. Since these differences exhibit no definite trend, they are probably caused by conditions other than exposure to soil heat.

\section{SUMMARY}

The time required for gladiolus to bloom was shortened from two to six weeks by heating the soil with electricity to a temperature of between $60^{\circ}$ and $70^{\circ} \mathrm{F}$.

Heating for about 60 days gave as good results as heating for about 100 days-in some cases better.

Heating for 35 days was beneficial but did not give as good results as heating for 60 or 100 days. 
The quality and number of spikes produced was not affected by heating the soil.

The cost of heating the soil depends upon the temperature maintained and the method of planting. With electricity at $\$ 0.02$ per kilowatt hour, the cost of heating the soil in an uncovered frame was $\$ 0.024$ per square yard per day for maintaining a temperature about $16^{\circ}$ above normal. In raised beds in the open field, the cost of heating was $\$ 0.039$ and $\$ 0.021$ per square yard per day for increasing the temperature $16^{\circ}$ and $11^{\circ}$, respectively. In frames covered with wax-impregnated muslin, the cost of heating was about $\$ 0.025$ per square yard per day for increasing the temperature $20^{\circ}$. 